\title{
Perceptions towards aging among selected Filipino adults
}

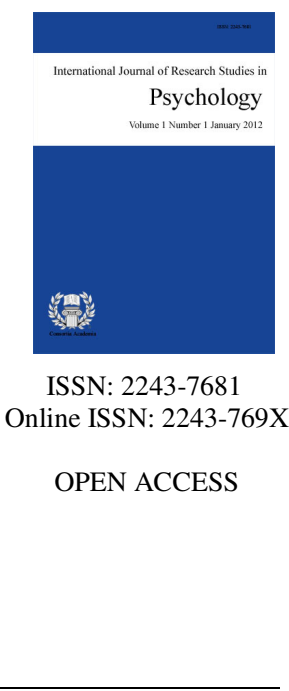

Valdez, Jana Patricia M

Colegio de San Juan de Letran-Manila, Philippines (janapatriciavaldez@yahoo.com)

Angeles, Julio L.

Colegio de San Juan de Letran-Manila, Philippines (julio.angeles@yahoo.com)

Pareja-Corpuz, Ernesita

Colegio de San Juan de Letran-Manila, Philippines (ecorpuz@letran.edu)

Hernandez, Christopher P.

Colegio de San Juan de Letran-Manila, Philippines (cphotrp@yahoo.com)

\section{Abstract}

The study aims to explore perceptions of selected Filipino adults towards aging. A total of twelve adults (6 married and 6 single) whose age ranges from 40 to 59 years old were recruited as participants. The study employed a qualitative-narrative research design. Participants were interviewed in accordance with their lived experiences and were analyzed through thematic analysis. The themes emerged from analyses of raw data are as follows: Aging as a responsibility; Aging as a maturation period; Aging as a promising experience; Aging as the process of increasing autonomy; Aging as a phase of increased productivity; Aging as a positive experience; Aging as a stage of physiological; and physical decline and aging as an apprehensive process. Implications of the study are discussed.

Keywords: aging; Filipino adults; social learning theory 


\section{Perceptions towards aging among selected Filipino adults}

\section{Introduction}

As the society continues to evolve in a more differentiated place to live in, people undergo the same pace of changing as signs of physical and psychological growth which is known as the process of ageing. It was seen that last 2006, there are already 500 million of aged people and was projected that by 2030, children will be outnumbered by people aged 65 and above in an estimate of an additional of 1 billion globally having the proportion of 1 in every 8 dwellers in every places of the earth (Ladarola, Maisano, Li, \& Li, 2007). Aging is a natural phenomenon that every individual has to face within the incessant years of their lives. However, it is somehow perceived by others as an anxiety provoking process because of their fear of experiencing developmental changes and utility of various anti-ageing supplements and processes (Hendricks, 2005).

Harman (2003) considered aging as a physiological process characterized by gathering harmful substances into the body that causes cells and tissues to die which can lead to the person's fragility in different illnesses. This biological change that occurs in every individual has always been an issue within the society (as cited in Lee, Lan, \& Yen, 2011). It has been remained vague and uncertain for people on how to address negative views toward aging. Nevertheless, coping to the inevitable aftermaths of aging still depends on the individuals' social, emotional and cognitive resources as interact with environmental and contextual factors (Kotter-Gru“hn, Kleinspehn-Ammerlahn, \& Gerstorf, 2009). In the middle of 20th century, global trend made an increase in the number of people who put their awareness in the idea of the process of aging (Lee, Lan, \& Yen, 2011).

In the Filipino culture, avoiding asking the age of a person, particularly when he or she is currently in the stage of adulthood, is a sign of respect. It is common as well for most adults to hide their ages or deny the fact that they are already aging. As cited in Kotter-Gru“hn, Kleinspehn-Ammerlahn, and Gerstorf (2009), there are studies done in the Western culture that age denial is a negative response in looking at the process of aging (Bultena \& Powers, 1978). However, other researchers have argued that actions of adults such as trying to look younger are manifestations of a healthy response to aging which can also be considered as a sign of their ability to adjust within their physical changes (Sneed \& Whitbourne, 2005). There are negative labels as well that younger generations have associated to adults such as loss of memory or slips of their memory and use the term "senior moment" which gives more negativity for the older people (Bennet \& Gaines, 2010).

Previous researches have also adressed negative stereotyping as one of the issues with regards to older people in the society which causes harmful effects to them (Levy \& Langer, 1994 as cited in Horton, Baker, Pearce, \& Deakin, 2010). There are several stages that an individual takes place in creating his or her perception about aging. The person imagines his or her self as an adult first as he generates his or her primary perception. Second is his or her perception when he or she is already part of the "old age" as whether by the identification of the society or by other people which can also be defined as self-stereotyping from age stereotyping. Lastly is on how they categorize other people as member of their group or not (Levy, 2003 as cited in Macia, Lahmam, Baali, Boëtsch, \& Chapuis-Lucciani, 2009). Younger people tend to say positive words whenever they are asked to forsee their selves growing old possibly because of their thinking to have a desirable response (Remedios, Chasteen, \& Packer, 2010) but actions can be hardly seen form them as they apply it to the current adults. It also reported that adults who negatively perceive aging are more prone to have illnesses and worse, die (Levy \& Myers, 2005).

Based on such studies, aging appeared to be a matter that has gained the interest of some researchers who are coming from sociological and psychological paradigm. Majority of the researches have focused on describing how the society is making sense of the aging process and how it can allow individuals to acquire such understanding. However, there seemed to be lack of researches that emphasized how people are perceiving aging 
as a physiological and psychological process. The researchers look on how the adults perceive aging when they were still a child and now that they are grown up. This is an important issue that deserved attention since awareness of the dynamics of aging process can lead psychologists towards formulating new and innovative ways on how to deal with problems of the general population about aging.

\section{Adult's experiences in aging}

Numerous studies have categorized adult's perception in aging in two ways: Positive and negative (Macia, Lahmam, Baali, Boëtsch, \& Chapuis-Lucciani, 2009; Branscombe \& Schoemann, 2010; Kotter-Gru“hn, Kleinspehn-Ammerlahn, Gerstorf, \& Smith, 2009; Levy \& Myers, 2005). Adults who consider themselves as experienced, wise and at the higher level of the society are the people who look at aging in a positive and healthy way (Macia, Lahmam, Baali, Boëtsch, \& Chapuis-Lucciani, 2009). On the other hand, older people who see themselves as useless, weak, socially unaccepted and dying are the one who perceive aging negatively (Branscombe \& Schoemann, 2010). These two subtypes were often associated by former researches to their health conditions. It revealed that those who perceived positively often live a healthy life while those who have negative perceptions frequently suffer from various ilnesses such as cardiovascular disease (Hendricks, 2005; Kotter-Gru“hn, Kleinspehn-Ammerlahn, Gerstorf, \& Smith, 2009; Levy \& Myers, 2005).

In the Philippines, adults have found out to be most likely supported financially by their chidren and living with their families compare to Western countries who are commonly being left at carehomes (Glasser, 2004 as cited in Ogena, 2006). However, Ofstedal and her co-authors have argued that Filipino elders are both receiver and provider as they also give financial support on their children or grandchildren (Ogena, 2006). More so, Filipino values in the milieu of family ties is the frequent reason coming out from the studies about the issues of aging in Filipinos (Ogena, 2006; Concepcion, 2012).

\section{Method}

\subsection{Research design}

The current study utilized qualitative research in answering the research questions. Specifically, narrative analysis was used to make sense of what have happened with the participants through extracting the deeper meaning of such personal accounts and integrating our own experiences in the course of data analysis (Bamberg, 2011).

\subsection{Participants}

The researcher selected twelve adults who were categorized into two groups: six participants that are married ( 3 male and 3 female) and six that are single (3male and 3 female) and age ranges from 40-59 from different communities in Metro Manila. Purposive sampling technique was employed as a mode of selecting the participants. Criteria were set in selecting participants to ensure that those who were chosen represent the target population. This safeguards both internal and external validity (Tongco, 2007). Thus, criteria include the following: a.) midlevel socioeconomic status; b.) Filipino citizen; and c.) absence of prominent psychological disorder.

\subsection{Data analysis}

To interpret the data collected, thematic analysis was used. Every after interview, its audio-recordings were transcribed. Coding was the first step that was performed. Line per line analysis was done in order to identify the possible meanings of what the participants have expressed. Those analyses were categorized in accordance with their similarities. Emergent themes or concepts from each transcript were identified and the insights gained every time the data are processed were noted as a way to reduce the biases in the course of analyzing the participants' 
responses. The same procedure was executed to all transcripts (Braun, \& Clarke, 2006). The emergent themes from all transcripts were examined again against the raw data (transcripts) and insights of the researchers through memo notes.

\section{Results}

This section presents the results taken after recording and transcribing the interview sessions conducted to twelve (12) adult respondents. Data strands that manifested similar meanings were clustered together to form the themes. Descriptions of themes were integrated in the elaboration of each theme.

\subsection{Aging as a responsibility}

Most of the participants viewed aging to be full of responsibilities. This idea was created through their experiences with their parents as they see them on how they handle their family. It is the idea of being a role model, having a stable job and managing one's family. One of the participants said: "when $i$ was still a child my view in aging is more responsibilities or duty" and as we talk about his current feelings through his experiences towards it he also expounded: "well right now, there are really responsibilities attached to aging like being mature enough to handle complicated situations and maintaining stable career and life situation... like that..." Another participant shared: "ayun iniisip mo lang psychologically hindi ka pwedeng nagiisip ka lang sa sarili mo, kasi may pamilya kang binubuhay dapat mas maging responsible ka di gaya ng mga nakagawian mo nung kabataan mo." These conceptions further assert that aging is a process linked to various life tasks that are expected by significant others and the society.

\subsection{Aging as a maturation period}

This theme means that when they were still a child, they also view aging as the stage of being mature or capable of handling various situations in a better and stronger manner than before. It is also a period when decision-making capabilities and problem-solving strategies independently develop. For an instance, one participant shared: "with my status right now, l can see thru aging l got more matured in my decision making". More so, one of them stated: "because we only realized that we are maturing as we get along with those experiences, instances that we've been through".

\subsection{Aging as a promising experience}

Almost all the participants revealed that they were excited or eager to be an adult when they were still a child because of various reasons such as being allowed to wear adults' clothes or have a developed body. They have associated aging with glamour and style. This theme represents their intense likeliness towards aging to achieve immediate satisfaction. As one respondent said: "nung bata ako sa mga damit, yung pag nakakakita ako ng adult na naka get-up na, naka heels na, gusto ko ganun”. And she also added:” kaya ako, jusko sabi ko, ba't antagal, parang looking forward ako dun, nung ganung age ako, sabi ko parang gusto ko na maging dalaga, gusto ko na lahat, ayoko na maging bata". Another participant shared: "I already tried putting high heels, make-up, teasing my hair... yan kasi ang mga nakikita ko rin sa lola ko nun eh. Tuwang-tuwa naman yung lola ko na bihisan ako. Kaya ayun, nag-enjoy na din ako at naging excited (laughing)”.

\subsection{Aging as a phase of increased productivity}

Majority of the married participants surprisingly perceived aging in a positive way by seeing it as the stage of being equipped with all the personal achievements and family the person have gathered throughout his/her life. It is the stage where one has the credibility to share his/her personal experiences, learning and ideas in life. As one of them said: "The reason why we are doing the present activity, yun nga yung pagtitinda dito, is that I wanted to continue touching people's lives hindi ba? Mentoring...coaching young people, kasi ako sa academe talaga ako eh... that they might attain excellence in different endeavours they wish to do... Kami, dito... marami 
na kaming napasaya dito, kami na rin kasi ang pinaka matanda dito eh (laughing)". The common to these participants is their perception of how beautiful aging is because of being surrounded with all the significant people in your life especially your family.

\subsection{Aging as a positive experience}

Despite the negative factors linked to aging, it was an ecstatic feeling to see that all of the married participants agreed that aging is still a positive experience as it serves as the phase of having second chances with all the mistakes they have done during their childhood years through the help of their family and the stage where they experience being respected, privileged and regarded as developed individual. As one participant shared: "And also having near excellent upbringing, I consider myself more blessed, more successful, well-respected and contented of what I have attained so far. Surrounded with loving family, grandchildren and friends, I couldn't ask for more". In addition, another participant stated: "Experience wise, aging does nothing but give you a big favor. It helps you learn from every right and every mistake. These signify that aging entails greater opportunities to become happier and more satisfied with their lives. Among the factors that contribute to their perception of aging as a positive experience include family, friends, career and professional advancement.

\subsection{Aging as a stage of physiological and physical decline}

All of the participants perceived aging in a manner that it gives both physical and physiological decline such as having different illnesses, weakening of cognitive functions and loss of attractiveness. As one participant stated: "Well, of course, ayan na yung nagkakasakit ko na.. or you are already vulnerable with sicknesses kaya you should already be careful with your choice of food and also your health". Another participant shared: "And ofcourse, ayan na noh, there is a sign of reduced beauty and mental alertness, naku, diba ayan talaga..." Others have highlighted the idea of having common physical pains such as arthritis, mental deterioration like memory gap and physical changes such as having wrinkles and skin discoloration. In other words, there is a consistency on the notion that aging is a developmental period of physical changes and maturation.

\subsection{Aging as an apprehensive process}

This theme shows that aging is also perceived to be an anxiety-provoking developmental which can be connected to the first theme that aging is the time when one's body decline and the person is getting to be dysfunctional. It exemplifies all the negative thoughts towards aging which makes the person anxious or hesitant in this developmental process. As one of the participants shared: "Because honestly, aging scares me" Also, one of them reiterated that: "ay! Hindi ako maglu-look forward sa aging (laughing) kung pwede ko lang irewind, pwede baby ulit? Yung ganun..." Most of them wished to go back to their childhood life or perceives aging as something that should be disliked or feared because of negative changes it might bring or the feeling of being near to death. As one participant expressed: "view pero yeah that's what I think about aging on a realistic note it's a day closer to your death". The combination of biological, psychological, social, and cultural stressors associated with this phase makes adults susceptible to negative emotional states (i.e. anxiety and depression).

\section{Discussion}

The study aims to explore how Filipino adults perceive aging. Themes that emerged from analyzing the data strands include: Aging as a responsibility and Aging as a maturation period. Majority of the participants based their views of aging through their direct interactions with their parents and family. As they age, they experience and proved to themselves that aging was a responsibility because they had their own families to think or to maintain their lives such as having stable career.

The most common among them is their perspective that aging is the period for maturation. They perceived that older people around them face different nature of problems. Since they are accountable in providing the needs of their families, they recognize the essence of maturity in the aging process. As an adult, they expressed 
the need to enhance their decision-making skills independently and handle situations in a better manner. This can be explained through social cognitive learning theory of Albert Bandura wherein the participants made their parents as their model in order to create their own cognition about aging (Hergenhahn \& Olson, 2005) and as they personally experienced it, they were able to come-up with their own perception of aging shaped by past experiences.

Despite the beauty married participants see in aging, they could still never deny same with the single participants that aging means physiological and physical decline. Due to biological reasons, this natural process makes our body and mind weaker (Harman, 2003) which results to different illnesses like arthritis, Alzheimer disease and osteoporosis. It can also be explained that with all of the factors that may be related to aging, physical and physiological are the primary observed changes. Due to its negative effects, it is not surprising that it is also common to participants to perceive it as apprehensive.

Aging in late adulthood profoundly affects appearance, sensation, and motor abilities. An older adult's appearance changes as wrinkles appear and the skin becomes less elastic and thin. Hair thins and turns gray as melanin decreases, and height lessens perhaps by an inch or two as bone density decreases (Sneed \& Whitbourne, 2005). The double standard of aging applies to men and women in older adulthood just as it did in middle adulthood. Older men may still be seen as distinguished, while older women are labeled as grandmotherly, over the hill, and past the prime of life.

Also, it was social support resources of friends, family, and community that were most likely to predict older adults' positive perceptions. While the data do not enable us to explain the specific mechanisms that friends, families, and communities employ to create this significance, this is a critical part of understanding the process of family in aging. And while mechanisms likely vary by individual, family, and/or community, the importance of support in relation to elders' positive perceptions are clear.

When adults realize that they have adequate psychosocial support from their family, friends, and colleagues, they become grateful of their lives which may lead not only to positive perceptions but also happiness. In fact, gratitude was found to relate well with happiness as it facilitates realization of life's purpose and significance (Datu \& Mateo, 2013).

Consequently, the chance of moving towards the mastery of their respective developmental tasks may increase. Most of them develop wisdom, feel successsful with their lives and does not regret anything behind. In other words, they get to engage themselves in endeavors that would reflect their productivity not only in terms of their career but also on other spheres of their lives (i.e. personal and familial).

Previous studies (Macia, Lahmam, Baali, Boëtsch, \& Chapuis-Lucciani, 2009; Branscombe \& Schoemann, 2010; Kotter-Gru“ hn, Kleinspehn-Ammerlahn, Gerstorf, \& Smith, 2009; Levy \& Myers, 2005) supported the existence of two aging perceptions' categories (i.e. positive and negative). Findings of the present study which validated these categories of aging perceptions would have a conceptual and practical significance in studying individuals under this developmental phase. Awareness of the positive perceptions towards aging can lead to the development of interventions that aim at enhancing positive thoughts of at-risk individuals towards aging.

From the results, it can be concluded that adults perceive aging according to their distinct lived experiences. In particular, important social units play vital roles in the way they made sense of the aging process. In effect, perception of aging is socially-construed. This implies that creating perception towards aging is dependent on our personal and social experiences. As such, promotion of happiness and well-being among adults should involve allowing these individuals to realize the presence of positive psychological resources predictive of positive and optimistic perceptions towards aging. 


\section{References:}

Bamberg, M. (2011). Narrative Analysis. In H. Cooper (Ed.), APA handbook of research methods in psychology (Vol. 2): Quantitative, qualitative, neuropsychological, and biological (pp. 77-94). Washington, DC: APA Press.

Bennett, T., \& Gaines, J. (2010). Believing what you hear: The impact of aging stereotypes upon the old. Educational Gerontology, 36(5), 435-445. http://dx.doi.org/10.1080/03601270903212336

Concepcion, B. (2012). Close-knit families: Filipino culture. Embracing aging: families facing change. Retrieved August 12, 2013, from http://www.embracingaging.com/?Page $=3430 \% 7$ CClose-knit+families $\% 3 \mathrm{~A}+$ Filipino+culture

Datu, J. A. D., \& Mateo, N.J. (2013).The mediating impact of meaning in life on the link between gratitude and subjective well-being. Manuscript submitted for publication.

Edillo, M. T., Turiano, M. K., Reyes, J. A., \& Villanueva, C. L. (2012). The mediating role of social comparison in the relationship between choice-making orientation and subjective well-being. Philippine Journal of Counseling Psychology, 14(1), 13-28.

Guion, L. A., McDonald, D. C., \& Debra, D. (2002). Triangulation: Establishing the validity of qualitative studies. Florida, United States of America.

Hendricks, J. (2005). Aegism: Looking across the margin in the new millennium. Generations, 29(3), 5-7.

Hergenhahn, B., \& Olson, M. (2005). An introduction to theories of learning . Virginia: Pearson, Prentice Hall.

Horton, S., Baker J., Pearce, W., \& Deakin, J. M. (2010). Immunity to popular stereotypes of aging? Seniors and stereotype threat. Educational Gerontology, 36, 353-371.

http://dx.doi.org/10.1080/03601270903323976

Kotter-Gruhn, D., Kleinspehn-Ammerlahn, A., Gerstorf, D., \& Smith, J. (2009). Self-perceptions of aging predict mortality and change with approaching death: 16-year longitudinal results from the Berlin Aging Study. American Psychological Association, 24(3), 654-667.

Ladarola, A., Maisano, C., Li, R. M., \& Li, R. (2007). Why population aging matters: A global perspective. United States Department of Health.

Lee, P-L., Lan, W., \& Yen, T. W. (2011). Aging successfully: A four factor model. Educational Gerontology, 37(3), 210-227. http://dx.doi.org/10.1080/03601277.2010.487759

Levy, B., \& Myers, L. (2005). Relationship between respiratory mortality and self-perceptions of aging. Psychology and Health, 20(5), 553-564. http://dx.doi.org/10.1080/14768320500066381

Lovett, S., \& Pillow, B. (2010). Age-related changes in children's and adult's explanations of interpersonal reactions. Journal of Genetic Psychology, 171(2), 139-167. http://dx.doi.org/10.1080/00221320903548100

Macia, E., Lahmam, A., Baali, A., Boëtsch, G., \& Chapuis-Lucciani, N. (2009). Perception of age stereotypes and self-perception of aging: A comparison of French and Moroccan populations. Journal of Cross-Cultural Gerontology, 24, 391-410. http://dx.doi.org/10.1007/s10823-009-9103-0

Ogena, N. (2006). The low and slow ageing in the Philippines: Auspicious or challenging? Retrieved August 12, 2013, from http://www.univie.ac.at/impactofageing/pdf/ogena.pdf

Ouano, J., \& Pinugu, J. (2012). Social goals of Filipino adolescents: Do they contribute to student life satisfaction? International Journal of Research Studies in Psychology, 1(3), 43-51. http://dx.doi.org/10.5861/ijrsp.2012.296

Parslow, R., Lewis, V., \& Nay, R. (2011). Successful aging: Development and testing of a multidimensional model using data from a large sample of older Australians. The American Geriatrics Society, 59(11), 2077-2083. http://dx.doi.org/10.1111/j.1532-5415.2011.03665.x

Pilcher, J. (2010). What not to wear? Girls, clothing and "showing" the body. Children \& Society, 24(6), 461-470. http://dx.doi.org/10.1111/j.1099-0860.2009.00239.x

Remedios, J., Chasteen, A., \& Packer, D. (2010). Sunny side up: The reliance on positive age stereotypes in descriptions of future older selves. Self and Identity, 9(3), 257-275. http://dx.doi.org/10.1080/15298860903054175 
Valdez, J. P. M., Angeles, J. L., Pareja-Corpuz, E., \& Hernandez, C. P.

Robinson, E. J., Pendle, J. E., Rowley, M. G., Beck, S. R., \& McColgan, K. L. (2009). Guessing imagined and live chance events: Adults behave like children with live events. British Journal of Psychology, 100(4), 645-659. http://dx.doi.org/10.1348/000712608X386810

Schoemann, A. M., \& Branscombe, N. R. (2011). Looking young for your age: Perceptions of anti-aging actions. European Journal of Social Psychology, 41(1), 86-95. http://dx.doi.org/10.1002/ejsp.738

Smith, J., \& Osborn, M. (2007). Interpretative phenomenological analysis. In J. A. Smith (Ed.), Qualitative psychology: A practical guide to research methods (pp. 53-80). London: Sage Publications.

Sneed, J., \& Whitbourne, S. K. (2005). Models of the aging self. Journal of Social Issues, 61, 375-388. http://dx.doi.org/10.1111/j.1540-4560.2005.00411.x

Tongco, M. D. (2007). Purposive sampling as a tool for informant selection. Ethnobotany Research \& Applications, 5, 147-158.

Toyama, N. (2011). Japanese children's and adults' reasoning about the consequences of psychogenic bodily reactions. Merill-Palmer Quarterly, 57(2), 129-157. http://dx.doi.org/10.1353/mpq.2011.0008

Yau, J., Smetana, J. G., \& Metzger, A. (2009). Young Chinese children's authority concepts. Social Development, 18, 210-229. http://dx.doi.org/10.1111/j.1467-9507.2008.00463.x 